work, we confidently appeal to all to raise a worthy monument to his memory.

It is proposed that this monument should consist of a marble bust on a stone pedestal, protected in a suitable manner from the inclemencies of the weather, to be placed in the Botanical Gardens at Zurich, on the spot where Heer's energy was so well displayed. 'The price of the memorial would reach about 5000 francs.

Besides which, the sculptor, M. Hörbst, is prepared to execute, for 150 francs each, plaster casts of the original. If you desire one of these copies, have the goodness to inform us, when sending your contribution. Subscriptions will be gratefully received by Dr. C. Schröter at Hottingen, Zurich. They may be sent direct, or through the medium of the undersigned.

Prof. Dr. A. Mousson, Polytechnikum, Zurich.

Prof. Dr. C. Cramer, ,

\title{
OBITUARY.
}

\section{PROFESSOR A. VON LASAULX PH.D.}

$W$ deeply regret to have received tidings of the death of this distinguished German Geologist and Mineralogist, which took place at Bonn, on the 25th January last, after a short illness. Dr. Von Lasaulx was only in his 47th year; yet he had been the autbor of a remarkably large number of Memoirs on petrological subjects, as well as of more solid works, of which, perhaps, the joint work on Etna of Sartorius von Waltershausen and himself is the most splendid example. In 1876 Dr. von Lasaulx, in company with his friend Dr. Ferdinand Roemer, of Breslau, visited the British Isles; and was present at the meeting of the British Association in Glasgow in that year. On his return to Bonn, he published an account of his wanderings, in the form of a handsome hook, "Aus Irland, Reiseskizzen und Studien," in which the physical features and geological structure of the districts visited are closely noted and graphically described, together with the mineral characters and composition of many of the rocks as determined under the microscope; of these, the most important was the discovery of tridymite in the trachytic rocks of Antrim (Petrographische skizze aus Irland; mineralogischen und petrographischen Mittheilungen, Wien, 1878, p. 410). The volcanic rocks of Bonn and the neighbourhood afforded a rich field for the petrological investigations of this lamented naturalist, of which he made abundant use.

E. H.

We regret to record the death (on the 16th February, from heartdisease) of Mr. W. W. Leighton, who, since the year 1867, has filled the office of Clerk to the Geological Society of London, and has during 19 years been a most faithful and valued servant to the Society. 